\title{
Rendszer az egészségügyi weboldalak hitelesítésére
}

\author{
Horváth Tamás dr. ${ }^{1,2}$ - Matics Katalin ${ }^{3}$ - Meskó Bertalan dr., ${ }^{4}$ \\ ${ }^{1}$ ENT House Budapest, Budapest \\ ${ }^{2}$ Bajcsy-Zsilinszky Kórház, Fül-Orr-Gégészeti Osztály, Budapest \\ ${ }^{3}$ Webline Trend Kft., Budapest \\ ${ }^{4}$ The Medical Futurist Institute, Budapest \\ ${ }^{5}$ Semmelweis Egyetem, Általános Orvostudományi Kar, Magatartástudományi Intézet, Budapest
}

\begin{abstract}
Bevezetés és céllitüzés: Az online egészségügyi felvilágosítás megbízhatatlan minősége új és komoly kihívás elé állítja az orvosi szakmát. Ha a weboldalakat hitelesség szempontjából minősítjük, akkor növeljük az esélyét, hogy a beteg jobb szakmai minőségú információhoz jusson. Magyarországon eddig nem történtek gyakorlati lépések az online betegfelvilágosítás minőségének ilyen irányú javítására.

Módszer: Az EgészségKommandó elnevezésú, az egészségügyi honlapok hitelességét vizsgáló magyar, objektív szempontrendszer 2017 augusztusa óta múködik nyilvánosan, és elismert indikátorokat használ (transzparencia, tartalom, ajánlás, hivatkozások).

Eredmények: Segítségével 2017. október 10-ig 122 weboldalt értékeltünk, és a meghatározott megfelelési küszöböt (21/27 pont) a honlapok 22,1\%-a (27/122) teljesítette, míg a JAMA-benchmark ajánlása szerint történő átvilágításuk során csak 1 weboldalt találtunk hitelesnek $(0,8 \%)$. A leggyakoribb hiányosságnak a hivatkozások mellőzése bizonyult, csak a honlapok 15,6\%-ában volt rendszeresen (>25\%) jelezve az információ eredeti forrása, valamint csak a weboldalak 18,9\%-án volt feltüntetve, hogy a leírtak nem helyettesítik a betegvizsgálatot. Szintén kiemelendő, hogy a honlapok 35,8\%-ában nem volt nyilvános a szövegek szerzője, viszont pozitívum, hogy az összes vizsgált oldal csaknem felében $(45,9 \%)$ orvosok írják a tartalmat, elérhetőséggel.

Következtetés: Az EgészségKommandó a különböző jellegű hitelességi és minőségi indikátoroknak egy megfelelésiküszöb-alapú pontrendszerben való alkalmazásával hatékonyan értékeli az egészségügyi felvilágosítással foglalkozó weboldalakat. Az elismert indikátorok többszörös hiányossága esetén kizárja a hitelességet, tehát szür, viszont különböző jellegű weboldalakat is képes egy rendszerben értékelni, ráadásul a magyar online egészségügyi szférához mérten mennyiségében tud ajánlani a betegeknek információforrást.
\end{abstract}

Orv Hetil. 2018; 159(13): 511-519.

Kulcsszavak: internet, egészségügy, információ, hitelesség

\section{An objective scoring system to evaluate the credibility of health related websites}

Introduction and aim: The unreliable quality of online health contents poses a serious challenge to the medical profession. Evaluating websites on the basis of their credibility increases the chance for readers to access professional content of better quality. Hungary still lags behind in taking practical steps to improve the quality and reliability of online patient education.

Method: EgészségKommandó (HealthCommando) is a new Hungarian objective scoring system established to evaluate the credibility of health related websites. It uses four types of indicators: transparency, content, recommendations, references.

Results: We evaluated 122 websites with EgészségKommandó. Out of this, 22.1\% qualified as credible. The same assessment using JAMA benchmarks yielded only one credible website $(0.8 \%)$. The most frequent deficiencies were the absence of reference to source, the omission of the quote that "the website information does not replace the doctor-patient discussion", and the identity of the author. In $45.9 \%$ of the cases, however, the content was written by medical professionals with contact information.

Conclusion: By applying different types of credibility and quality indicators in a scoring system, EgészségKommandó can efficiently assess the websites on health-awareness. In cases where the recognized indicators are absent multiple 
times from a website, it will not pass the credibility test. Thus, EgészégKommandó can act as a filter. At the same time, EgészségKommandó is also capable of assessing webpages of different sorts systemically, and can recommend a proportionately large amount of reliable Hungarian medical web resources to those interested.

Keywords: internet, healthcare, information, credibility

Horváth T, Matics K, Meskó B. [An objective scoring system to evaluate the credibility of health related websites]. Orv Hetil. 2018; 159(13): 511-519.

(Beérkezett: 2017. november 22.; elfogadva: 2017. december 27.)

A magyar betegek háromnegyede tájékozódik egészségügyi problémája kapcsán az interneten, $48 \%$-uk pedig az egészségével kapcsolatban elsődleges információforrásnak az internetet nevezi meg [1], a nemzetközi megfigyelésekhez hasonlóan [2]. Mivel az interneten bárki, egészségügyi végzettség és tapasztalat nélkül is előállíthat és továbbadhat egészségügyi tartalmat, a gyakorló orvosok napi szinten találkoznak hamis vagy pontatlan információval felvértezett betegekkel. Ezen betegek esetében az előzetesen az internetről szerzett téves információ nem segíti, sőt hátráltatja a szakmailag megfelelő betegút kialakítását. A nem megbízható egészségügyi információ akár tartós egészségkárosodást, a legrosszabb esetben halált is jelenthet, de ártalmatlanabb betegségek, egészségi problémák esetében is felesleges kiadást okoz, növeli a várólistákat, illetve késik a diagnózis felállítása és a terápia megkezdése.

$\mathrm{Az}$ online egészségügyi információ minősége széleskörűen vizsgált terület. Nemrég publikált összefoglalónkban fül-orr-gégészeti példákon keresztül mutattuk be a laikus felvilágosítással foglalkozó, betegségekről, azok kezeléséről szóló weboldalak minőségével kapcsolatos kutatásokat [3]. Az eredmények szerint a honlapok rendkívül egyenetlen színvonalon, megbízhatatlan módon tájékoztatják a betegeket, ráadásul minél inkább krónikus, illetve az orvostudomány által nehezen kezelhető fül-orr-gégészeti betegségekről, egészségi problémákról van szó, annál inkább anyagilag erősen befolyásolt, gyakran tisztán reklámcélú tartalomhoz jutnak a betegek - már az orvossal való találkozás elött. Egy 165, különböző szakterületeket érintő, az egészségügyi honlapok minőségével foglalkozó kutatásokat elemző összefoglaló közlemény hasonló eredményre jutott: a publikációk több mint felében $(55,2 \%)$ alapvetóen nem megfelelő átlagos színvonalról számoltak be a független tanulmányok szerzői [4].

A problémára univerzális megoldás nincsen, viszont több szinten, többféleképpen is be lehet avatkozni az online egészségkommunikációt javítva $[3,5]$. Az egyik lehetőség, hogy egy szempontrendszer segítségével minősítjük a honlapokat, és a hiteles információt tartalmazó weboldalakat kiemeljük. Ilyen minősítésre példa a nemzetközi szinten elismert, angol nyelvú, svájci székhelyú Health on the Net alapítvány HONcode elnevezésú tanúsítványa: ez egyfajta igazolás a weboldal hitelességét illetően [6], melyet a minősítésen átesett honlap üzemeltetője kitehet a weboldalára. A HONcode kritériumrendszeréhez hasonló alapelveket fogalmazott meg a National Institutes of Health (NIH) [7] és a Journal of Medical Associations (JAMA) [8], de számos további, az online információ hitelességét elbíráló szempontrendszer is publikálásra került az elmúlt években [4], melyek különböző minőségi indikátorokra fókuszáltak. Az ilyen jellegú hitelességi vizsgálaton való megfelelés önmagában még nem jelent garanciát a minőségi tartalomra, azaz hogy szakmailag biztosan helyes információt talál az interneten a beteg, viszont az esélyét egyértelmúen növeli [9-11].

Habár tudományos szempontból a fenti minősítési rendszerekkel már számos vizsgálat történt, a HONcode az egyetlen, gyakorlatban is alkalmazott minősítőeszköz az angol nyelvú online felületeken, melynek hitelességét ugyanakkor némileg csökkentette fizetôssé válása. Ráadásul az angollal szemben kifejezetten szúk spektrumú, magyar nyelvú, egészségügyi felvilágosítással foglalkozó honlapok esetében a HONcode nem nyújt segítséget az információt kereső betegeknek, és egy 2006-ban publikált hazai elemzéshez viszonyítva [12] az elmúlt 10 évben sem magának a HONcode-nak a használata, sem annak elvei nem kerültek be érdemben a magyar online egészségügyi szférába. Az irodalom alapján, valamint saját tapasztalatainkat felhasználva $[3,13-15]$ létrehoztunk egy, a magyar nyelvú egészségügyi honlapok hitelességét vizsgáló objektív kritériumrendszert, amely elismert indikátorok segítségével a transzparencia és a szakmaiság különböző aspektusait vizsgálja, és alkalmas az egészségügyi felvilágosítással foglalkozó honlapok hitelességének megítélésére. A szempontrendszer az EgészségKommandó (e-kommando.hu) keretein belül múködik. Az alábbiakban ennek alkalmazását és a gyúijtött tapasztalatokat kívánjuk bemutatni.

\section{Módszer}

A hitelesség megítélésére olyan rendszert hoztunk létre, amely az eddig publikált, az online egészségügyi tartalom parametrikus minőségi indikátorai közül egy skálát fog át. A lehetséges, a tudományos kutatásokban leggyakrabban vizsgált indikátorokat és azok közül az álta- 
lunk alkalmazott kritériumokat az 1. ábra mutatja be. Az online platformokkal kapcsolatos technológiai indikátorok nem kerültek beválasztásra, mert a hitelesség szempontjából indifferensek. Ugyanezen okok miatt nem kerültek be a formai indikátorok közül az olvashatóságot vizsgáló objektív módszerek. Doménspecifikus (szakterület-specifikus) indikátorok beválasztására nem volt lehetőség, mivel nem szakterület-specifikus hitelesítési rendszer létrehozása volt a cél, a jogszabályok nem megfelelő alkalmazása pedig automatikus kizárás formájában, totális módon került alkalmazásra. Az eszköz célközönsége a betegek; a vizsgált indikátorok a laikus kommunikációt elősegítendő két alrendszerbe kerültek besorolásra: transzparencia és szakmaiság, egyenként 5-5 kérdéssel.

A transzparenciára vonatkozó kérdések:

- Nyilvános-e a weboldal célja? (Transzparenciaindikátor.)

- Nyilvános-e az üzemeltető kiléte? (Transzparenciaindikátor.)

- Nyilvánosak-e a bejegyzések szerzői? (Transzparenciaindikátor.)

- Jelzett, hogy mikor került oda az adott tartalom? (Transzparenciaindikátor.)

- Megjelenik-e reklám az oldalon? Ha igen, saját vagy hirdetéskiszolgáló rendszert használ? (Általános tartalmi indikátor.)

A szakmaiságra vonatkozó kérdések:

- A honlap független, vagy egy adott egészségügyi termék/eljárás támogatására, illetve direkt kereskedelmi céllal jött-e létre? (Általános tartalmi indikátor.)
- Jelölve van-e a honlapon, hogy az ott közzétett információ nem helyettesíti a betegvizsgálatot, csak kiegészítő jellegü? (Általános tartalmi indikátor.)

- Mi a szöveg szerzőinek végzettsége? (Általános tartalmi indikátor.)

- Ajánlja-e a weboldalt hivatalos egészségügyi szakmai szervezet, jelentős, elismert civil egészségügyi szervezet, egészségügyi kiadó? (Ajánlások.)

- Jelölve van-e a tartalomnál a forrás? (Hivatkozás.)

A kérdésekre adott válaszok pontrendszerben kerülnek értékelésre, melyben maximálisan 27 pontot lehet elérni. Egy hasonlóan széles indikátorskálájú, pontrendszeren alapuló minősítőrendszert bemutató kutatás során $75 \%$ feletti teljesítés esetén minősítették hitelesnek az egészségügyi felvilágosítással foglalkozó honlapokat [16]. Ezt irányadónak elfogadva, a jelenleg bemutatott EgészségKommandó-szempontrendszerben 21 pont $(77,7 \%)$ jelenti a hitelességi küszöböt.

A kizárólagos megfelelési kritériumok helyett alkalmazott pontrendszer lehetőséget nyújt különböző jellegű weboldalak (nagy egészségügyi portálok, szakmai blogok, állami vagy magánfinanszírozású egészségügyi intézmények weboldalai, civil szervezetek honlapjai stb.) egy rendszerben való értékelésére, mivel a hitelesség más módon jelenik meg az egyes honlaptípusokon, azaz más indikátorok segítségével lehet mérni.

Kizárólag olyan weboldalak kerülnek értékelésre, amelyeken nyilvánosan, regisztráció nélkül érhető el laikus vagy szakmai egészségügyi felvilágosító tartalom, és amelyek deklarált célja a felvilágosítás. A vizsgálat során

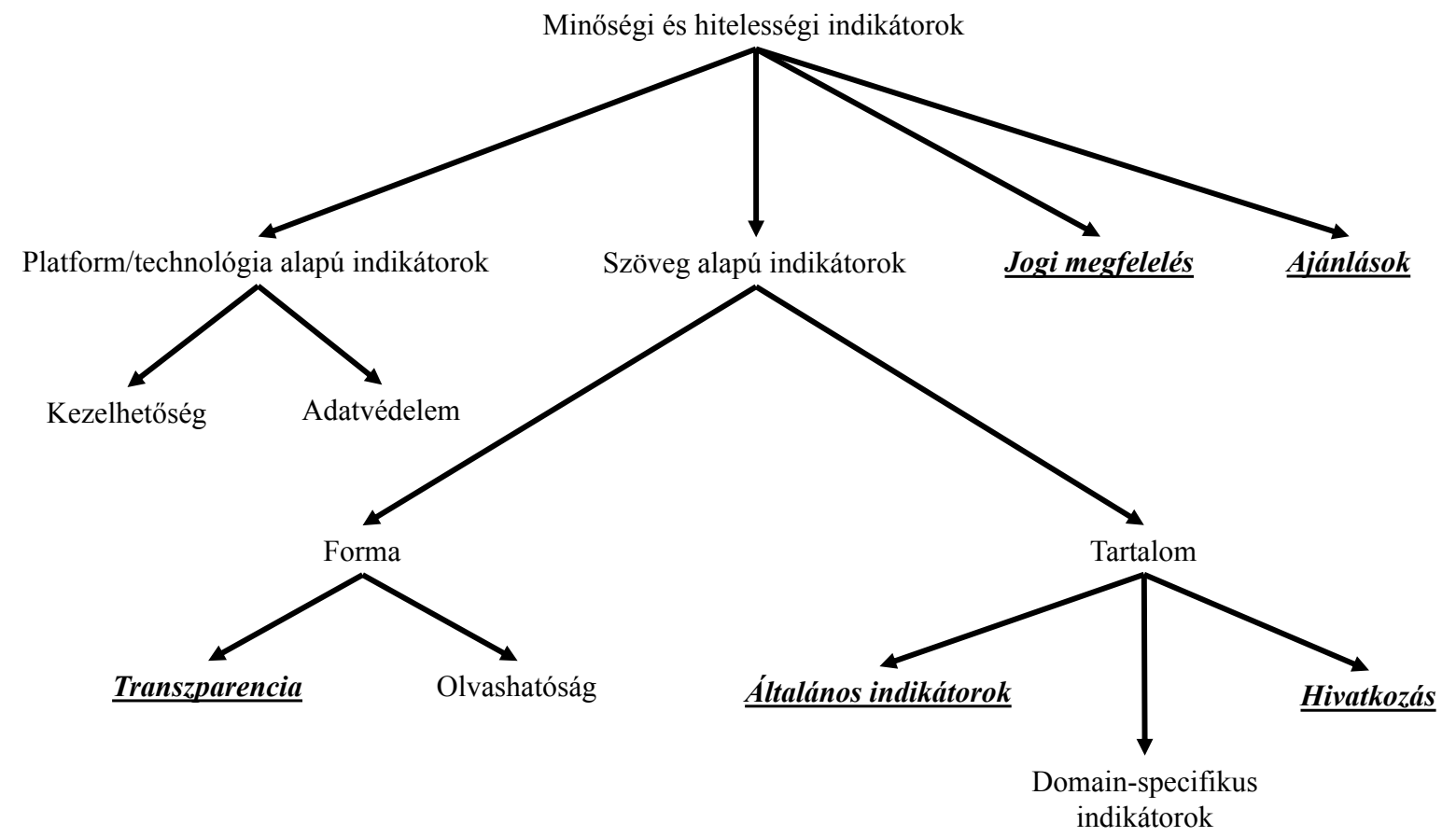

1. ábra

A jelentősebb, elismert, minôségi és hitelességi indikátorok sematikus ábrázolása

Dőlt betúvel és aláhúzva az EgészségKommandó szempontrendszerében is alkalmazott indikátorok 
kétszintű értékelés történik két különböző vizsgáló által. Minden honlapon véletlenszerúen legalább 10 tartalomegység (betegségleírás, cikk, bejegyzés, hír) átvizsgálása történik; 500 feletti tartalomegység esetén legalább 20 tartalomegység alapján zajlik a minősítés. Amennyiben egy weboldal a kritériumrendszerben való értékelés során hitelesnek minősül, úgy az EgészségKommandó honlapján a „Hiteles weboldalak” listáján, szakterületek szerinti bontásban ajánlásra kerül, valamint az adott honlap üzemeltetői kitehetnek egy „Hiteles egészségügyi weboldal" elnevezésü pecsétet a weboldalukra. A minősítés évente felülvizsgálatra kerül. Ha egy minősítést kérő honlap nem felel meg a szempontrendszerben, akkor a weboldal üzemeltetói értesítést kapnak, hogy mely indikátorok hiánya vagy nem megfelelő szintje miatt nem kapták meg a 'hiteles honlap' minősítést. Ezek korrigálása esetén a weboldal üzemeltetői ismételten kérhetik a hitelesítést.

A jelen vizsgálatban a 2017. május 1. és 2017. október 10. között átvilágított oldalak minősítésének eredményeit dolgoztuk fel. A pontozórendszer teszteléséhez kulcsszavas keresést alkalmaztunk a kapott találati oldalak beválogatásával, amihez a hazánkban is leggyakrabban használt keresőt, a Google-t vettük igénybe. Magyar nyelvű keresést végeztünk, és csak magyar nyelvű találatokat vettünk figyelembe. A keresés során kizártuk a halott linkeket, a linkgyưjjő oldalakat és a kizárólag regisztráció után elérhető tartalommal rendelkező weboldalakat, az ugyanarra az URL-re (Uniform Resource Locator, webcím) vezető találatokat pedig egynek kezeltük. A keresés során nőgyógyászati kulcsszavakat használtunk, melyek alapját a második szerző által üzemeltetett, tematikus nőgyógyászati portálon (Intima.hu) leggyakrabban előforduló 50 szakmai kulcsszó adta. Ebből az 50 kulcsszóból a Google kulcsszótervezőjének (adwords.google. hu/KeywordPlanner) segítségével kiválasztottuk a Google magyar nyelvű keresőjében a 2017. február és május között leggyakrabban használt 10 kulcsszót (terhesség; menstruáció; fogamzásgátlás; endometriosis; klimax; pajzsmirigy-alulmüködés; inzulinrezisztencia; policisztásovárium-szindróma; változókor; incontinentia). Ezzel a 10 kulcsszóval a fenti kritériumok mellett keresést végeztünk. A keresés során minden egyes kulcsszónál az első 10 olyan találatot vettük figyelembe, amely weboldalakon laikus vagy szakmai célú egészségügyi tájékoztató tartalmak érhetők el. A 10 kulcsszóval való keresés egyenként első 10 találata alapján 100 találatból álló bázist képeztünk, melyet az adott kulcsszavakra való találati gyakoriság és a keresóben elért találati hely alapján értékeltünk, és az értékelés alapján a legelső helyezettel kezdve az összes találatot az EgészségKommandópontrendszerben értékeltük. Ezt követően 2017. augusztusban nyilvánossá tettük a pontozórendszert, és a továbbiakban az EgészségKommandó nyilvánosan elérhető e-mail-címére beküldött weboldalakat a hitelesség szempontjából értékeltük.
A honlapok elért pontértékeit elemeztük, és összehasonlítottuk a minősítésen megfelelt és a minősítésen nem megfelelt weboldalak elért eredményeit. Az EgészségKommandó szempontrendszere szerint átvilágított honlapokat az ún. JAMA-benchmark 4-es kritériumai szerint is megvizsgáltuk [8]. A JAMA szerkesztősége által tett ajánlás tartalmazza a legkevesebb elvárt indikátort egy kritériumrendszerbe helyezve, és a következő paraméterek jelenlétét kéri számon az egészségügyi felvilágosítással foglalkozó weboldalakon: a szöveg szerzője személyének feltüntetése; a szöveg eredeti forrására való hivatkozás; a honlap üzemeltetőjére, elsősorban szponzorációjára vonatkozó transzparencia megléte; valamint az adott tartalom keletkezésének pontos dátuma.

\section{Eredmények}

2017. május és 2017. október között 189, minősítésre ajánlott vagy minősítést kérő honlapból 122 weboldalon fordult elő mérhető mennyiségü, laikus vagy szakmai egészségügyi felvilágosítással foglalkozó tartalom. Az EgészségKommandó szempontrendszere szerinti hitelességi vizsgálaton ez a 122 honlap esett át, melyek közül elsőre 24 nyerte el a 'hiteles weboldal' minősítést. A második körben - miután egyes, a minősítést igénylő honlapok teljesítették a hiányzó kritériumokat - további 3 weboldal minősült hiteles forrásnak. Így összesen az átvizsgált honlapok 22,1\%-a (27/122) nyerte el a 'hiteles’ minősítést.

A weboldalak átlagosan 15,4 pontot értek el a vizsgálat során, ebből a hitelesnek minősített honlapok átlagos pontértéke 22,4 pont volt, míg a nem megfelelt honlapok átlagosan 13,5 pontot teljesítettek. Az elérhető maximális 27 pont tükrében a minósítésen nem megfelelt honlapok átlagos pontértéke legalább 3, legfeljebb 6 minőségi indikátor hiányosságát feltételezi az adott weboldalakon. Az egyes honlapok által elért pontszámokat a 2. ábrán jelenítettük meg.

A kérdésekre adott válaszok lehetséges maximális pontértékeit és ez alapján az összes vizsgált honlap átlagára vonatkozó százalékos eredményeket a 1 . táblázatban mutatjuk be. Mindegyik átvilágított weboldal esetében egyértelműen deklarálták a honlap létrejöttének célját $(99,2 \% ; 121 / 122)$, csak 1 honlapnál $(0,8 \%)$ nem derült ki, hogy miért hozták létre. Az oldalak 92,6\%ának esetében lehetett tudni, hogy ki vagy milyen szervezet áll a weboldal mögött, és csak 86,9\%-ban adták meg az üzemeltető elérhetőségét is. A honlapok 7,4\%-ában nem lehetett megtudni az oldalon, hogy ki tartja fenn a honlapot.

Ami a konkrét tartalmakat illeti, az átvizsgált oldalak 20,5\%-ában a szöveg szerzőjének nevével együtt az elérhetősége is meg volt adva, 19,7\%-ban csak név, kapcsolati lehetőség nélkül, míg 24,6\%-ban szórványosan, 36\%ban pedig egyáltalán nem volt feltüntetve a szöveg szerzője. A weboldalak $82,8 \%$-a vagy nem jelenített meg reklámcélú tartalmat a felületen, vagy pedig egyedi hir- 
detés keretében tette, míg 17,2\%-nál hirdetéskiszolgáló rendszerben, szüretlenül jelentek meg hirdetések. A honlapok 59\%-án volt jelölve a szöveg publikálásának ideje, viszont csak 5,7\%-án frissítették a régi tartalmakat, az oldalak $41 \%$-án nem.

A vizsgált weblapok 95,9\%-a nem egy adott egészségügyi termék vagy eljárás támogatására, illetve direkt vásárlás elérésére (például webshop) jött létre, csak 5 esetben (4\%) volt egyértelmü, hogy elsődlegesen kereskedelmi célú az oldal. A honlapok 18,9\%-án volt jelölve, hogy az ott elhelyezett egészségügyi tartalom nem helyettesíti a vizsgálatot, az oldalak 81,1\%-án nem. A tartalmak szerzőinek végzettsége szerint, az oldalak $45,9 \%$-án minden esetben adott orvos volt megnevezve, 15,6\%-án minden esetben jelölve orvos és újságíró vagy nem orvos egészségügyi végzettségű volt a szerző, az esetek 12,3\%-ában több szerző, orvos, újságíró vagy nem orvos egészségügyi végzettségü mellett egyes tartalmaknál nem volt megnevezett szerző. A honlapok 3,3\%-án minden esetben jelzetten újságíró jegyezte a szöveget, 2,5\%-án szórványosan volt megnevezve szerző, és az ismert szerző(k) nem egészségügyi végzettségü(ek) voltak, míg a honlapok 20,5\%-ánál a szerző megnevezésének teljes hiánya miatt a végzettséget nem lehetett kideríteni.

A vizsgált 122 weboldal 28,6\%-ánál nem találtunk az adott oldalt támogató, elismert egészségügyi szervezetet vagy kiadót, míg a honlapok 71,3\%-a legalább egy, 21,3\%-a legalább 3 elismert egészségügyi szervezet vagy kiadó támogatását bírta, a weboldalon egyértelmúen jelezve. A szerzők a honlapok 15,6\%-án rendszeresen
(>25\%) hivatkoztak az információ eredeti forrására, de csak 9\%-ban tették ezt élő link formájában. Szórványos hivatkozás (0-25\%) 7,9\%-ban fordult elő, 56,6\%-ban pedig egyáltalán nem.

Az EgészségKommandó keretében is megvizsgált 122 honlapot a JAMA kritériumrendszere szerint is értékeltük. Az átvilágítás során azt találtuk, hogy összesen 1 olyan magyar egészségügyi felvilágosítással foglalkozó honlap van, amely minden szempontból megfelel a $J A M A$ szerkesztőségi ajánlásának, így hitelesnek minősíthető - ez a vizsgált weboldalak 0,8\%-a.

\section{Megbeszélés}

Az egészségügyi felvilágosítással foglalkozó honlapok hitelesség szempontjából történő ajánlása egy lehetséges megoldás a megbízhatóbb online betegfelvilágosításra. Egy ilyen szempontrendszer bevezetése több ponton is javíthat az online egészségkommunikáció minőségén. Egyrészt indirekt módon úgy, hogy az online egészségügyi információ minőségi problematikájának köztudatba kerülése felhívja a laikus felhasználók figyelmét a fokozott óvatosságra a tájékozódást illetően, tehát oktat. Másrészt szakterület-specifikus kérdőívek segítségével (doménspecifikus indikátorok) igazolták, hogy a konszenzusos kritériumokat alkalmazó hitelességi rendszerekben való megfelelés vagy az azokban elért nagyobb pontszám növeli az esélyét annak, hogy a betegek szakmailag jobb egészségügyi információval találkozzanak [9-11]. Végül, a szempontrendszert üzemeltető honlap-

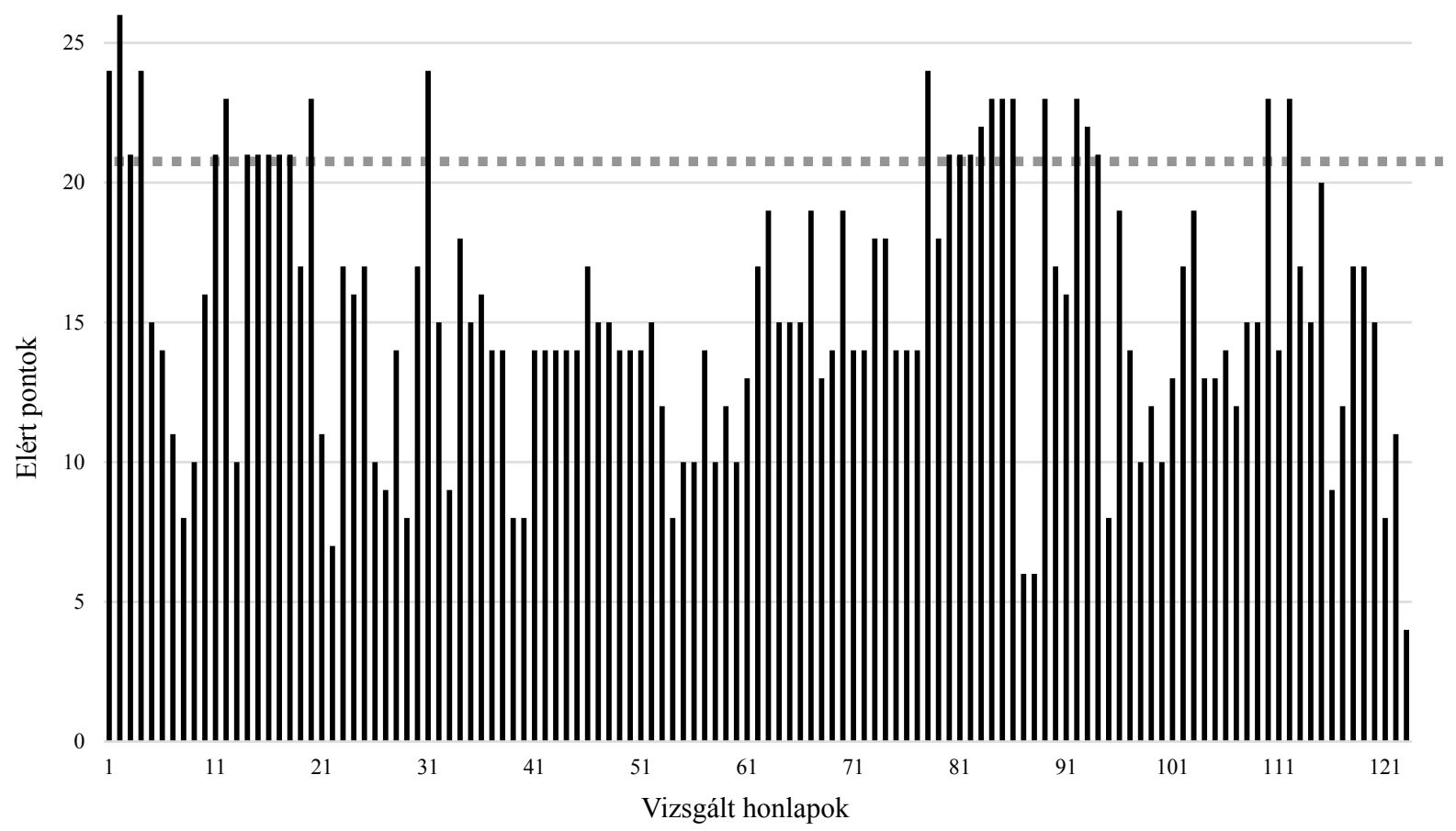

2. ábra

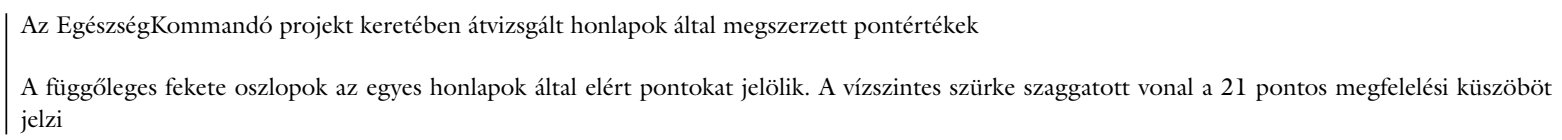


A kérdések, melyek segítségével a különböző indikátorok vizsgálata történt, valamint a válaszok, az értük kapható maximális pontok és az adott pontértéket teljesítő honlapok \%-ban megadva

\begin{tabular}{|c|c|c|c|}
\hline Kérdés & Válasz & $\begin{array}{l}\text { Elérhető } \\
\text { pontszám }\end{array}$ & $\begin{array}{l}\text { Az adott pontértéket } \\
\text { teljesítő honlapok }\end{array}$ \\
\hline \multirow[t]{2}{*}{ Nyilvános-e a weboldal célja? } & Igen & 2 & $99,1 \%$ \\
\hline & Nem & 0 & $0,9 \%$ \\
\hline \multirow[t]{3}{*}{ Nyilvános-e az üzemeltető kiléte? } & Megnevezett személy/szervezet, elérhetőséggel & 3 & $86,9 \%$ \\
\hline & Megnevezett személy/szervezet, elérhetőség nélkül & 2 & $5,7 \%$ \\
\hline & Nem & 0 & $7,4 \%$ \\
\hline \multirow[t]{4}{*}{ Nyilvánosak-e a bejegyzések szerzői? } & Minden esetben név és elérhetőség & 3 & $20,5 \%$ \\
\hline & Minden esetben név & 2 & $19,7 \%$ \\
\hline & Nem minden esetben & 1 & $24,6 \%$ \\
\hline & Nem & 0 & $36 \%$ \\
\hline \multirow{3}{*}{$\begin{array}{l}\text { Jelzett, hogy mikor került oda az adott } \\
\text { tartalom? }\end{array}$} & Igen, frissítéssel & 3 & $5,7 \%$ \\
\hline & Igen & 2 & $54,1 \%$ \\
\hline & Nem & 0 & $41 \%$ \\
\hline \multirow{2}{*}{$\begin{array}{l}\text { Megjelenik-e reklám az oldalon? Ha igen, saját } \\
\text { vagy hirdetéskiszolgáló rendszert használ? }\end{array}$} & Nincs reklám, vagy van, de saját rendszerben & 1 & $82,8 \%$ \\
\hline & Hirdetéskiszolgáló rendszer & 0 & $17,2 \%$ \\
\hline \multirow{2}{*}{$\begin{array}{l}\text { A honlap egy konkrét egészségügyi termék/ } \\
\text { eljárás támogatására jött létre? }\end{array}$} & Nem & 2 & $95,9 \%$ \\
\hline & Igen & 0 & $4 \%$ \\
\hline \multirow{2}{*}{$\begin{array}{l}\text { Jelölve van a honlapon, hogy az ott közzétett } \\
\text { információ nem helyettesíti a betegvizsgálatot? }\end{array}$} & Igen & 2 & $19,9 \%$ \\
\hline & Nem & 0 & $81,1 \%$ \\
\hline \multirow[t]{6}{*}{ Mi a szöveg szerzőinek végzettsége? } & Orvos/egészségügyi végzettségű & 5 & $45,9 \%$ \\
\hline & Orvos/egészségügyi végzettségű + újságíró & 4 & $15,6 \%$ \\
\hline & $\begin{array}{l}\text { Nem minden esetben jelölt, ahol igen, ott orvos/ } \\
\text { egészségügyi végzettségú + újságíró }\end{array}$ & 3 & $12,3 \%$ \\
\hline & Újságíró & 2 & $3,3 \%$ \\
\hline & $\begin{array}{l}\text { Nem minden esetben jelölt, ahol igen, ott újságíró, } \\
\text { vagy mindig jelölt, de nem egészségügyi végzettsé- } \\
\text { gű/újságíró }\end{array}$ & 1 & $2,5 \%$ \\
\hline & Nem jelölt & 0 & $20,5 \%$ \\
\hline \multirow{3}{*}{$\begin{array}{l}\text { Ajánlja-e a weboldalt hivatalos egészségügyi } \\
\text { szakmai szervezet, jelentős, elismert civil } \\
\text { egészségügyi szervezet, egészségügyi kiadó? }\end{array}$} & Igen, legalább 3 & 3 & $21,3 \%$ \\
\hline & Igen, $1-3$ & 1 & $50 \%$ \\
\hline & Nem & 0 & $28,6 \%$ \\
\hline \multirow[t]{4}{*}{ Jelölve van-e a tartalomnál forrás? } & Lehetőség szerint igen ( $25 \%$ felett), linkkel & 3 & $9 \%$ \\
\hline & Lehetőség szerint igen (25\% felett), link nélkül & 2 & $6,6 \%$ \\
\hline & Ritkán $(1-25 \%)$ & 1 & $27,9 \%$ \\
\hline & Nem & 0 & $56,6 \%$ \\
\hline
\end{tabular}

ról való linkelés a klasszikus, orvostudományban is alkalmazott citációnak megfelelően az érintett, hitelesség szempontjából megfelelt honlapoknak a keresókben való rangsorolását javítja [17].

A korábban publikálásra került, hitelességre, illetve minőségre vonatkozó ajánlások közül a legkevesebb, minimálisan elvárható indikátor jelenlétét a JAMA szerkesztősége által javasolt kritériumrendszer kéri számon a honlapokon [8]. Megvizsgáltuk, hogy az általunk minősített weboldalak között hány olyan van, amely a JAMA szerkesztőségi kritériumai szerint hitelesnek bizonyulna, és azt találtuk, hogy összesen csak 1 ilyen honlap van a 122-ből, ami $0,8 \%$. Ez az alacsony megfelelési arány a mindennapok felól megközelítve hátrányos, sôt nem elfogadható, ha nem angol, hanem magyar nyelvú honlapokra gondolunk. Azzal ugyanis, hogy csak nagyon kevés weboldalt tudunk ajánlani, egyes egészségügyi témákat, szakterületeket illetően pedig lényegében semmit, a beteget a rendszerben csalódva végül mégis magára hagyjuk az egészségével kapcsolatos információ 
megszerzésében. Ennek a jelenségnek a javítására lehet alkalmas pontrendszeralapú, a hitelességi küszöb szerint bíráló szempontrendszerünk, mely úgy tud több indikátort elbírálni, hogy közben nem szúküil tovább az amúgy sem széles ajánlási paletta. Az EgészségKommandó minősítési rendszerében a vizsgált honlapok $21,9 \%$-a felelt meg, ami majdnem 2 nagyságrenddel jobb a JAMA-kritériumok alapján történő hitelesítési rátánál, és ez az arány a weboldalak üzemeltetőinek oktatása révén valamelyest tovább növelhető, tehát a szürés mellett tud érdemben információforrást nyújtani a betegeknek.

Szempontrendszerünk múködésének vizsgálata során azt találtuk, hogy a hitelesnek minősített oldalak átlagos pontértékei és a nem megfelelt oldalak pontértékei között jelentős különbség van. A retrospektív módon végzett, nem experimentális környezetben való mérés miatt statisztikai megközelítésből a rendszer hatékonyságára vonatkozó következtetéseket nem tudunk levonni, de az eredmény azt mutatja, hogy jelenleg Magyarországon az elismert indikátorok jelenlétét illetően élesen elkülönülnek a weboldalak, mely eltérés egyébként megfelelő szándék esetén, számos honlapon könnyen javítható.

Még több tanulság levonható viszont abból az eredményből, hogy a hitelességi minősítésen nem megfelelt oldalak átlagos pontértéke legalább 3 elismert minőségi indikátor hiányosságát jelenti, de akár 6 kisebb pontértékű indikátorét is. Ez vagy 3 teljesen különböző jellegű indikátor lehet (forma, tartalom, ajánlás), vagy a - kérdések felépítéséból adódóan - a legelismertebb és leggyakrabban alkalmazott indikátorok (forma, tartalom) többszörös hiányosságából tevődik össze.

Az egészségügyi weboldalak minősítésével foglalkozó 2015. évi összefoglaló által elemzett 165 cikkben a leggyakrabban vizsgált paraméter a szövegalapú indikátorok formai vonatkozású transzparenciaindikátorai voltak [4]. Ezek közül is az egészségügyi tartalmak szerzőinek nyilvános volta a leginkább elvárt indikátor, ennek vizsgálatát 124 cikkben alkalmazták. A megbízhatóság, a hitelesség vizsgálata során ténylegesen is talán a legfontosabb elvárás, hogy ismert legyen a szöveg szerzője. Ennek jelentőségét figyelembe véve érdekes és szomorú, hogy az EgészségKommandó keretein belül átvizsgált magyar honlapok 35,8\%-ában egyáltalán nincs feltüntetve a szöveg szerzője, 24,4\%-ában is csak szórványosan, ezzel szembeállítva a weboldalak 20,3\%-ában volt még elérhetőség is megadva a szerző neve mellett.

Egy 2002-ben készült felmérés szerint az egészségügyi információra vadászó laikusok nem elsősorban a szöveg szerzőinek kilétére és végzettségére (általános tartalmi indikátor) kíváncsiak, és ez alapján fogadnak el hitelesnek egy weboldalt, hanem a platform/technológiai indikátorok ennél fontosabbnak bizonyultak [18]. Ezzel szembeállítható, hogy depresszióval foglalkozó honlapok vizsgálata során negatív korrelációt fedeztek fel az esztétikum és a tartalom minősége között, amiből arra következtettek, hogy a weboldalak üzemeltetői sok esetben külsőségekben próbálják pótolni vagy elfedni a tar- talmi, szakmai hiányosságokat [9]. Ezek is megerősítik, hogy az egészségügyi tartalmak hitelességének kérdésében nem lehet fontosabb egy weboldal menürendszerének kezelhetősége, mint a szöveg létrehozójának hozzáértése, amire a szerző kilétének ismeretéből következtethetünk. Az általunk vizsgált honlapok 45,9\%-án egyébként egyértelmúen kiderült, hogy a tartalmak szerzői a hitelesség szempontjából leginkább autentikus orvosok voltak.

A fentiek arra is figyelmeztetik a szakmát, hogy a laikus olvasókat oktatni kell a megfelelő online egészségügyi információ keresésére, javítva az ún. e-Health literacy-t, azaz a laikusok képességét a hatékonyabb egészségügyi célú internethasználatra, valamint tájékoztatni kell őket a hitelesség ismérveiről, ami nem lehetetlen feladat. Kísérletes környezetben már több kutatás is igazolta a laikusok ilyen irányú képességeinek fejleszthetőségét [19], és az EgészségKommandó ebben is segítséget nyújthat. A fenti kutatások másik tanulsága, hogy törekedni kell az egészségügyi honlapok felhasználóbarát kialakítására, megjelenítésére és könnyű kezelhetőségére, valamint az online egészségügyi információ létrehozása során figyelembe kell venni a felhasználók további, egyébként öszszetett és variábilis igényeit, keresési motivációit is [20, 21 ]. Ebben maguk a betegek, elsősorban az egészségükért aktívan tevő, az internet adta lehetőségeket jól kihasználó e-páciensek tudnak talán a legtöbbet segíteni, de maga az EgészségKommandó kritériumrendszere is útmutató a szakmának abban, hogy milyen szempontok megjelenítésére kell törekedni az egészségügyi tartalmak online publikálása során.

Az EgészségKommandó szempontrendszere szerint történt vizsgálat folyamán a magyar honlapok leggyakoribb hiányossága a honlapon megjelentetett információ kiegészítő jellegének jelölése volt. A weboldalak 81,1\%án nem szerepelt, hogy a fellelhető egészségügyi tartalom nem helyettesíti a betegvizsgálatot, miközben például HONcode minősítést csak olyan honlap kaphat, ahol ez egyértelmúen fel van tüntetve. Hasonlóképpen az információ eredeti forrásának megnevezése is nagyon gyakori hiányosságnak bizonyult, az általunk minősített honlapok 54,5\%-ában egyáltalán nem jelölték meg az információ forrását. Pedig azon túl, hogy ez is az egyik kritérium a HONcode elnyerésére, a NIH-ajánlás és a $J A M A$ szerkesztősége szerint is fontos jelzője a minőségnek és ezzel együtt a hitelességnek. Az evidence-based medicine (bizonyítékokon alapuló orvoslás) korában a kutatásokra, tankönyvekre vonatkozó hivatkozás mellőzése komolyan csökkenti az információ minőségét és hitelességét. Ráadásul azzal, hogy az elmúlt években a hangsúly a szakmai információ publikálását illetően is egyértelmúen átkerült az internetre, és az eredeti források, tankönyvek, orvosi folyóiratok is megtalálhatók az világhálón, a hivatkozások linkként történő megjelenítésével könnyedén egy kattintásnyira elérhetővé lehet tenni a citált szakmai anyagokat. 
Az egészségügyi információ létrejöttének, a szöveg megszületésének ideje szintén az egyik leggyakrabban alkalmazott minőségi indikátor a neten, ráadásul ennek detektálása akár számítógép által vezérelve is történhet, ami a hitelességi vizsgálatok automatizálásának irányába is mutat [22]. Zhang és mtsai 108 olyan cikket találtak, amelyben a weboldalak minősítése során ezt is vizsgálták [4]. Ennek jelentősége, hogy az orvostudomány gyors fejlődése révén a szakmai ajánlásokban, az egyes betegségek patomechanizmusára vonatkozó teóriákban vagy a kezelési elvekben jellemzően pár évente változás következik be. Így minél régebben született egy cikk az interneten, annál kevésbé hiteles, viszont mindenképpen hitelesebb, mint az a tartalom, amelyet nem lehet elhelyezni az időben. Szerencsére a vizsgált magyar honlapok többségénél ez egyértelmüen jelölve van, de 40,2\%-a nem tüntette fel a felvilágosító tartalom keltezését, ami - a gyorsan és periodikusan változó szakmai állásfoglalásokat figyelembe véve - csökkenti az adott oldalakon található információ hitelességét.

Pozitívumként kell elkönyvelni, hogy csak egyetlen, minősítésen átesett honlapnál $(0,8 \%)$ nem derült ki, hogy valójában miért is jött létre az adott honlap, és öszszesen csak 7,4\%-ban nem volt nyilvános, hogy ki üzemelteti a weboldalt. Emellett a vizsgált honlapok 82,8\%-a nem hirdet az oldalon, vagy ha igen, azt nem hirdetéskiszolgáló rendszerben teszi, ami elsődlegesen a reklámok megfelelő szürési lehetőségét jelenti. Csak 5 olyan honlapot találtunk (4\%), amelyet direkt valamilyen egészségügyi terméknek vagy eljárásnak dedikáltak, vagy esetleg az elsődleges cél a közvetlen eladás volt (például webáruház), de mégis szerepelt az oldalon egészségügyi felvilágosító célú tartalom. Attól még, hogy egy oldal el akar adni valamit, a felvilágosítás szempontjából lehet hiteles, bár a függetlenség ilyen jellegű hiánya csökkenti az oldal értékét ebben a vonatkozásban. Szempontrendszerünket többek között e miatt a jelenség miatt is pontrendszeralapon hoztuk létre.

Az üzleti jelleggel mint a hitelességet némileg csökkentő tényezővel szemben előnyként kell értékelni, ha egy weboldalt ajánlanak hasonló vagy még autentikusabb információforrások. Az, hogy ajánlanak-e egy honlapot, elég egyértelmúen és könnyen kideríthető, általában a „Partnereink”, „Támogatóink” és hasonló elnevezésû menüpontok alatt található azon szervezetek listája, amelyek az adott oldalt elismerik.

\section{Következtetés}

Összességében elmondható, hogy az egészségügyi felvilágosítással foglalkozó honlapok hitelesség szempontjából történő minősítése javít az online egészségkommunikáció minőségén, a betegek a hitelesnek talált weboldalakon nagyobb eséllyel találkozhatnak szakmailag is jobb minőségü információval. A magyar nyelvü honlapok esetében az eddig publikált kritériumrendszerek alkalmazásával csak nagyon szúk palettáról lehet ajánlani a betegeknek egészségügyi információt, de ezen segít az elismert indikátorokat alkalmazó, pontozásalapú szempontrendszer, amely ráadásul különböző jellegú honlapok hitelességének értékelésére képes egyazon rendszerben.

Anyagi támogatás: A közlemény megírása, illetve a kapcsolódó kutatómunka anyagi támogatásban nem részesült.

Szerzôi munkamegosztás: H. T.: A módszer kidolgozása, a kézirat elkészítése. M. K.: A módszer kidolgozása, adatgyưjés, lektorálás. M. B.: A módszer kidolgozása, lektorálás. A cikk végleges változatát valamennyi szerző elolvasta és jóváhagyta.

Érdekeltségek: A szerzőknek nincsenek érdekeltségeik.

\section{Irodalom}

[1] Házipatika.com. Az Év Magánrendelője verseny a lakosságot is edukálja. Available from: http://www.cmsales.hu/a-magyarlakossag-fele-nem-tudja-milyen-esetben-kell-orvoshoz-fordulnia-a-hazipatika-com-szervezeseb?division=web [accessed: June $8,2016]$.

[2] Mueller J, Jay C, Harper S, et al. Web use for symptom appraisal of physical health conditions: A systematic review. J Med Internet Res. 2017; 19: e202.

[3] Horváth T, Varga Zs. Health-related information on the internet: benefits, problems, solutions. [Online egészségügyi információ: pozitívumok, problémák, megoldások.] Orvostovábbk Szle. 2017; 24: 70-73. [Hungarian]

[4] Zhang Y, Sun Y, Xie B. Quality of health information for consumers on the web: a systematic review of indicators, criteria, tools, and evaluation results. J Assoc Inf Sci Technol. 2015; 66: 2071-2084.

[5] Kincses Gy. Can we have guide-posts in the Babel of information? [Lesznek-e útjelzők az információk Bábelében?] IME 2016; 15(7): 7-10. [Hungarian]

[6] Boyer C, Selby M, Scherrer JR, et al. The Health On the Net Code of conduct for medical and health websites. Comput Biol Med. 1998; 28: 603-610.

[7] National Institutes of Health. How to evaluate health information on the Internet: questions and answers. Available from: https://ods.od.nih.gov/Health_Information/How_To_Evaluate_Health_Information_on_the_Internet_Questions_and_Answers.aspx [accessed: June 24, 2011].

[8] Silberg WM, Lundberg GD, Musacchio RA. Assessing, controlling, and assuring the quality of medical information on the Internet: Caveant lector et viewor - Let the reader and viewer beware. JAMA 1997; 277: 1244-1245.

[9] Zermatten A, Khazaal Y, Coquard O, et al. Quality of web-based information on depression. Depress Anxiety 2010; 27: 852-858.

[10] Nassiri M, Bruce-Brand RA, O'Neill F, et al. Perthes disease: The quality and reliability of information on the Internet. J Pediatr Orthop. 2015; 35: 530-535.

[11] Bruce-Brand RA, Baker JF, Byrne DP, et al. Assessment of the quality and content of information on anterior cruciate ligament reconstruction on the Internet. Arthroscopy 2013; 29: 10951100.

[12] Geges J, Juhász É, Vasas L. Content informatics and professional analysis of Hungarian health-related websites. [Magyar egészségügyi honlapok informatikai és szakmai elemzése.] Orv Hetil. 2006; 147: 1033-1040. [Hungarian] 
[13] Horváth T. The revolution of the information from the doctor's perspective. [Az információs forradalom orvosi szemmel.] Lege Artis Med. 2011; 21: 494-496. [Hungarian]

[14] Meskó B, Dubecz A. New facilities provided by the medicine and internet. [Az orvostudomány és a világháló nyújtotta új lehetôségek.] Orv Hetil. 2007; 148: 2095-2099. [Hungarian]

[15] Meskó B. The importance of social media to clinical practice. Clin Pract. 2014; 11: 31-33.

[16] Thompson AE, Graydon SL. Patient-oriented methotrexate information sites on the Internet: a review of completeness, accuracy, format, reliability, credibility, and readability. J Rheumatol. 2009; 36: 41-49.

[17] Stanford Digital Library Working Paper. The PageRank Citation Ranking: Bringing Order to the Web. January 29, 1998. Available from: http://ilpubs.stanford.edu:8090/422/1/1999-66. pdf [accessed: June 1999].

[18] Eysenbach G, Köhler C. How do consumers search for and appraise health information on the world wide web? Qualitative study using focus groups, usability tests, and in-depth interviews. BMJ 2002; 324: 573-577.
[19] Lee K, Hoti K, Hughes JD, et al. Interventions to assist health consumers to find reliable online health information: a comprehensive review. PLoS ONE 2014; 9: e94186.

[20] Lee K, Hoti K, Hughes JD, et al. Dr Google and the consumer: a qualitative study exploring the navigational needs and online health information-seeking behaviors of consumers with chronic health conditions. J Med Internet Res. 2014; 16: e262.

[21] Zhang Y. Beyond quality and accessibility: Source selection in consumer health information searching. J Assoc Inf Sci Technol. 2014; 65: 911-927.

[22] Wang Y, Liu Z. Automatic detecting indicators for quality of health information on the Web. Int J Med Inform. 2007; 76: $575-582$.

(Horváth Tamás dr., Budapest, Rácz Aladár u. 94/G, 1121 e-mail: horvatht@gmail.com)

"Error corrigitur, ubi invenitur."

(A hibát ott kell kijavítani, ahol elkövették.)

\section{A rendezvények és kongresszusok híranyagának leadása}

a lap megjelenése előtt legalább 40 nappal lehetséges, a 6 hetes nyomdai átfutás miatt. Kérjük megrendelőink szíves megértését.

A híranyagokat a következő címre kérjük: Orvosi Hetilap titkársága: edit.budai@akademiai.hu Akadémiai Kiadó Zrt. 